\title{
Alignment of new bathing water EU directive and its applications to protect public health
}

\section{Halk sağlığının korunması için yeni yưzme suyu $A B$ direktifinin uyumlaştırılması ve uygulamaları}

\author{
Dilek DiKMEN¹, Hasan IRMAK
}

\begin{abstract}
Introduction: The twinning project entitled "Alignment in Bathing Water Monitoring" was implemented within the framework of EU Pre-Accession Financial Assistance IPA I-2010 Programming by the Ministry of Health, Public Health Institution of Turkey together with France-Italy consortium between the I. quarter of 2013 and II. quarter of 2015. The major aims of the project was to transpose the new bathing water Directive 2006/7/EC into the Turkish National Legislation and strengthening the bathing water quality monitoring system of Ministry of Health - Public Health Institution of Turkey within the framework of the new directive.

Methods: The project was designed such as to ensure the alignment of the new bathing water Directive 2006/7/EC and preparation of the draft bylaw on bathing water quality management, transition from 76/160/EEC to 2006/7/EC Directive regarding the classification and quality assessment of bathing water starting gradually with the pilot applications and then disseminating to the whole bathing areas, the practice of establishing experimental bathing water profiles in the selected areas of the pilot provinces, compiling of sets of bathing water quality data, improvement of the bathing water quality monitoring system of the Ministry of Health in the direction of 2006/7/EC Directive, improvement of the technical capacity of the Public
\end{abstract}

\section{ÖZET}

Amaç: AB Katılım Öncesi Mali Yardım Aracı IPA I-2010 Programlaması kapsamında alınan "Yüzme Suyunun İzlenmesinde Uyum" bașlıklı eșleștirme projesi, Sağlık Bakanlığı, Türkiye Halk Sağlığı Kurumu ile Fransa-İtalya konsorsiyomu işbirliğinde 2013 I. çeyreği ile 2015 II. çeyreği arasında yürütülmüștür. Projenin başlıca amaçları yeni yüzme suyu direktifi 2006/7/EC'nin uyumlaștırılarak ulusal mevzuata aktarılması ve bu yeni direktif doğrultusunda Sağlık Bakanlığı, Türkiye Halk Sağlığı Kurumu’nun yüzme suyu izleme sisteminin güçlendirilmesidir.

Yöntem: Proje; yeni yüzme suyu direktifi 2006/7/ EC'nin uyumunun yapılarak Yönetmelik taslağının hazırlanması, yüzme suyunun sınıflandırılması ve kalite değerlendirmesine yönelik 76/160/EEC direktifinden 2006/7/EC direktifine geçişin aşamalı olarak pilot uygulamalar șeklinde bașlayarak tüm yüzme alanlarına yaygınlaştırılması, pilot illerin seçilialanlarında deneysel profil olușturmak üzere uygulamaların yapılması, yüzme suyu kalite veri yönetimine yönelik çalıșmaların yapılması, Sağlık Bakanlığı'nın yüzme suyu kalitesi izleme sisteminin 2006/7/EC Direktifi doğrultusunda geliștirilmesi ve halk sağlığı laboratuvarlarının yeni yüzme suyu direktifi doğrultusunda yapmaları gereken

'The Ministry of Health, Public Health Institution of Turkey, Ankara, Turkey

İletisim/Corresponding Author : Hasan IRMAK

Adnan Saygun Cad. No: 55 N Blok Kat: 2 No: 6 Sıhhiye 06420 Ankara - Türkiye

Tel : +903125655351
E-posta /E-mail : hsn.irmak@gmail.com
Geliş Tarihi / Received : 31.05 .2016 Kabul Tarihi / Accepted : 24.07.2016

DOI ID : 10.5505/TurkHijyen.2016.83436

Dikmen D, Irmak H. Alignment of new bathing water EU directive and its applications to protect public health Turk Hij Den Biyol Derg, 2016; 73(4): 395-404 
Health Laboratories to perform analysis according to the new bathing water directive.

Results: The draft "By-law on bathing water quality management" has been prepared with the transposition of 2006/7/EC EU Directive by the Ministry of Health, Public Health Institution of Turkey with the contribution of the relevant institutions. Trainings and workshops were organized. Six guidance documents were prepared, published and distributed. Data quality assessment and classification practice were done at pilot provinces Antalya, Çanakkale and İstanbul.

Conclusion: The all activities given in the project contract have been successfully completed and all project mandatory results were reached. The technical and institutional capacity for the full implementation of the 2006/7/EC Directive by the Ministry of Health was impoved successfully with the project.

Key Words: bathing water, public health, 2006/7/ EC directive, twinning project analizler için teknik kapasitelerini güçlendirmek üzere tasarlanmıștır.

Bulgular: 2006/7/EC Avrupa Birliği Direktifinin uyumlaștırılmasıyla "Yüzme Suyu Kalitesinin Yönetimine Dair Yönetmelik Taslağı” ilgili kurumların da katkısı ile Sağlık Bakanlığı, Türkiye Halk Sağlığı Kurumu tarafından hazırlanmıștır. Eğitimler ve çalıștaylar düzenlenmiștir. Altı Rehber Kitap hazırlanmıș, bastırılmıș ve dağıtılmıștır. Veri kalite değerlendirmesi ve sınıflandırma pratiği, pilot iller olan Antalya, Çanakkale ve İstanbul'da gerçekleștirilmiștir.

Sonuç: Proje kontratında yer alan aktivitelerin tamamı bașarıyla gerçekleștirilmiș ve tüm zorunlu hedeflere ulașılmıștır. Proje ile Sağlık Bakanlığı'nın 2006/7/EC Direktifini tam olarak uygulaması için gerekli olan teknik ve kurumsal kapasite bașarıyla geliștirilmiștir.

Anahtar Kelimeler: yüzme suyu, halk sağlığı, 2006/7/EC direktifi, eșleștirme projesi

\section{INTRODUCTION}

Twinning which was originally designed in 1998, is an EU institution building instrument developed by the Commission and based on partnership cooperation between public administrations of EU Member States and a Beneficiary Country for the achievement of mandatory results jointly agreed with the Commission $(1,2)$.

It aims to help the beneficiaries in the development of modern and efficient administrations, with the structures, human resources and management skills needed to implement the EU acquis. Twinning is an important tool to assist national administrations in reaching the required level of institutional capacity by facilitating the sharing of Member States' experience and know-how (3).
Water-based recreation is an important component of leisure activities. Coastal waters, rivers and lakes are used for a variety of recreational activities, including swimming, diving, fishing and sailing. However, water-based recreation can also expose individuals to a variety of health hazards, ranging from exposure to potentially contaminated foodstuffs and potable water supplies, through to exposure to sunshine and ultra violet (UV) light and to bathing in polluted waters. The varied nature of the hazards to human health posed by recreational waters demands a full audit of the relative importance of the resultant health effects and the resources required to mitigate those effects (4). 
The first European bathing water legislation, "Council Directive concerning the quality of bathing water 76/160/ EEC" came into force in 1975. Its main objectives are to safeguard public health and protect the aquatic environment in coastal and inland areas from pollution. Bathing waters can be coastal waters or inland waters (rivers, lakes) $(5,6)$.

The second and the new European Legislation "Directive 2006/7/EC concerning the management of bathing water quality and repealing Directive 76/160/EEC was adopted in 2006 (7).

The new bathing water directive updates the measures of the 1975 legislation and simplifies its management and surveillance methods. It also provides a more proactive approach to inform the public about water quality using four quality categories for bathing waters as "poor", "sufficient", "good" and "excellent". The Member States brought into force the laws, regulations and administrative provisions in order to comply with this Directive by 24 March 2008. A period until 31 December 2014 was given to the Member States for the implementation of it $(7,8)$.

The new directive is intended to be based on scientific knowledge on protecting health and the environment, as well as environmental management experience, provide better and earlier information of public about quality of bathing waters, including logos, move from simple sampling and monitoring of bathing waters to bathing quality management, and be integrated into all other EU measures protecting the quality of all waters (rivers, lakes, ground waters and coastal waters) through the Water Framework Directive 2000/60/EC. Two main parameters intestinal enterococci and Escherichia coli are defined for analysis, instead of nineteen in the previous directive. These parameters will be used to monitor and assess the quality of bathing waters and to classify them. Other parameters could be taken into account, such as the presence of cyanobacteria or microalgae. Member States must monitor the bathing waters every year. The monitoring calendar should provide for at least four samples to be taken per season (except where the season is very short or where there are special geographic constraints). The sampling interval should not be longer than one month. Upon the monitoring results gathered in four years, Member States should assess the bathing waters at the end of every season. A shorter period may be acceptable in some cases. The waters are classified according to their level of quality: poor, sufficient, good or excellent, linked to clear numerical quality standards for bacteriological quality. Where water is classified as "poor", Member States should take certain management measures, e.g. banning bathing or posting a notice advising against it, providing information to the public, and suitable corrective measures. Member States should also prepare a description of bathing waters and the potential impacts and threats to water quality, both as an information for public and as a management tool for the responsible authorities, through the so-called bathing water profiles. They could include in particular a description of the area concerned, any sources of pollution and the location of the water monitoring points. Beyond the 1976 Bathing Water Directive, the new directive ensures timely information of the public during the bathing season, with an obligation for Member States to disseminate actively and promptly information on bathing water quality. In particular, notices banning or advising against bathing should be rapidly and easily identifiable. The EU Commission adopted on the 27 May 2011 a decision establishing a symbol for information to the public on bathing water classification and any bathing prohibition. Every year the EU Commission publishes a summary report on 
the quality of bathing water, based on the reports that the Member States should submit to it before the start of each bathing season (9).

Although the main objectives of the two directive 76/160/EEC and 2006/7/EC are to safeguard public health and protect environment from pollution, with the new directive, new topics such as new bathing water quality classification through the monitoring of the parameters intestinal enterococci, Escherichia coli, new calculation method required for the classification, bathing water profiles, compiling of bathing water quality data sets, cyanobacterial risks, information to the public, public participation, cooperation on transboundary waters were introduced $(7,10)$.

To form the required technical infrastructure in these subjects, to enhance the present infrastructure within the frame of the new Directive and to prepare the draft of the new by-law by doing the harmonisation studies, twinning project under the title of "Alignment in bathing water monitoring" was taken by Ministry of Health, Public Health Institution of Turkey.

The EU twinning project within the frame of EU Pre-Accession Financial Assistance IPA I - 2010 Programming was implemented with France - Italy consortium between the I. quarter of 2013 and II. quarter of 2015 (11).

Cooperation was provided between the French Ministry of Social Affairs and Health, International Office of Water (IOW), Italy Ministry of Health and Fondazione Minoprio Institute and Public Health Institution of Turkey - Environmental Health Department.

With the project it was aimed to transpose the new bathing water directive 2006/7/EC into the Turkish National Legislation and strengthening the bathing water quality monitoring system of Ministry of Health - Public Health Institution of Turkey within the framework of the new directive.

In the broader sense the aim of the project was to contribute to the reduction of public health risks and to ensure coordination, cooperation and data sharing between institutions and organizations in bathing waters (11).

\section{METHODS}

The project was established on the 6 main targets. Result 1: Regulation - The alignment of the new bathing water directive 2006/7/EC and preparation of the draft by-law. Result 2: Classification - Transition from 76/160/EEC to 2006/7/EC Directive regarding the classification and quality assessment of bathing water starting gradually with the pilot applications and then disseminating to the whole bathing areas. Result 3: Bathing Water Profiles - Practice of establishing experimental bathing water profiles in the selected areas of the pilot provinces. Result 4: Data Management - Compiling of sets of bathing water quality data. Result 5: Monitoring - Improvement of the bathing water quality monitoring system of the Ministry of Health in the direction of 2006/7/ EC Directive. Result 6: Laboratories -Improvement of the technical capacity of the Ministry of Health, Public Health Laboratories to perform analysis according to the new bathing water directive.

The method of the project implementation includes; current situation assessment of the regulations and of the applications on bathing water; evaluation of the Member State applications on 2006/7/EC Bathing Water Directive, analysis of the applications in France and in Italy as model applications, in place observations by study visits, GAP analysis, recommendations through outputs of GAP analysis, working group meetings (WGM), 
inter-ministerial meetings (IMM), pilot provincial meetings (PPM), experimental data evaluation, classification, establishment of profiles practices with pilot provinces, local visits to the pilot provinces - public health directorates and public health laboratories, trainings, workshops, preparation, publication and distribution of the guidance documents, project steering committee meetings.

Antalya, Çanakkale and İstanbul were selected as the pilot provinces for practical applications. The pilot applications and the activities concerning the project results 1, 2, 3, 4, 5 were carried out jointly with Antalya, Çanakkale and İstanbul public health directorates bathing water units.

Antalya, İstanbul and Samsun public health laboratories were participated in the project as pilot laboratories for the implementation of project 6th result.

The drafting studies of the by-law was carried out by the working group which was established with the participation of Public Health Institution of Turkey - Environmental Health Department, the Ministry of Environment and Urbanization, the Ministry of Forestry and Water Affairs, the Ministry of Culture and Tourism and the Ministry of Interior.

To share the developments in the project and to discuss the cooperation between institutions in the preparation of the by-law and bathing water profiles which require joint work, inter-ministerial meetings were done with the participation of the Public Health Institution of Turkey - Environmental Health Department, Public Health Laboratories Department, Strategy Development Department, EU Coordination Department of the Ministry, the representatives of the Ministry of Forestry and Water Affairs, the Ministry of Environment and Urbanization, the Ministry of Culture and Tourism, the Ministry of Interior, the representative of the Scientific and Technological Research Council of Turkey (TUBITAK), representative of Foundation for Environmental Education in Turkey (TURCEV), project team, Turkish, French and Italian project leaders. These meetings were done at the same date before the project steering committee meetings.

\section{RESULTS}

The project overall objectives was successfully achieved. The draft by-law was prepared with the transposition of 2006/7/EC EU Directive into the Turkish National Legislation. The coordination, cooperation and data sharing between institutions and organisations in bathing waters were developed. Progress directed to the importance of public health and reduction of probable public health risks was ensured.

The all project purposes were also successfully reached. A draft by-law was prepared with the transposition of 2006/7/EC EU Directive into the Turkish National Legislation. The technical capacity of the Ministry of Health - Public Health Institution of Turkey and the Public Health Directorates of the 34 Provinces were strengthened in monitoring the bathing water quality.

Current situation assessment was conducted through the presently used "By-Law on Bathing Water Quality" which was prepared in line with the EU Directive 76/160/EEC.

The draft "By-law on bathing water quality management" has been prepared with the transposition of 2006/7/EC EU Directive by the Ministry of Health, Public Health Institution of Turkey with the contribution of the relevant institutions. The comments of the institutions on the draft bylaw were received. Besides, the prepared draft by- 
law was evaluated and gap analysis was done by the French and Italian experts of the twinning project in view of the articles of the 2006/7/EC Directive. The improved draft by-law was worked by the working group which was established with the participation of the relevant institutions.

Comprehensive trainings were given to the technical staff of the Public Health Institution of Turkey, Environmental Health Department, Public Health Directorates of the 34 Provinces where bathing water quality monitoring activities are carried out, representatives of the relevant Ministries and organizations including Ministry of Environment and Urbanization, the Ministry of Forestry and Water Affairs, the Ministry of Culture and Tourism, the Ministry of Interior, the Scientific and Technological Research Council of Turkey (TUBITAK) and Foundation for Environmental Education in Turkey (TURCEV). Training was given also to the technical staff of the Public Health Institution of Turkey, Public Health Laboratories Department, Consumer Safety Laboratories Department, Public Health Laboratories of the 34 provinces, concerning bathing water analysis in the direction of 2006/7/EC EU Directive including applications, the used materials and equipments, laboratory quality assurance and quality control, laboratory accreditation.

Experimental profiles were established in the selected areas of the pilot provinces Antalya, Çanakkale and İstanbul as Antalya-Konyaaltı Beach (Konyaaltı Beach Park 2nd Beach), ÇanakkaleBozcaada Ayazma Beach, İstanbul-Riva Elmasburnu Beach. The applications were disseminated to all other 34 provinces by transferring the information about the activities done by the pilot provinces through training and workshop.

Methods for the classification of bathing water, for the establishment of bathing water profiles, for bathing water data management, for the bathing water quality monitoring and public information in accordance with the 2006/7/EC EU Directive were developed. Information about these subjects was given place in the prepared Guidance Documents.

Six Guidance documents were prepared by the French and Italian experts, published and distributed. "Guidance on Bathing Water Quality Classification (2006/7/EC)”, “Guidance on Bathing Water Profiles (2006/7/EC)”, “Guidance on Bathing Water Quality Data Management (2006/7/EC)”, “Guidance on Bathing Water Quality Monitoring (2006/7/EC)”, "Guidance on Cyanobacteria Proliferation in Bathing Waters (2006/7/EC)" for the Public Health Institution of Turkey, Environmental Health Department and the Public Health Directorates of the 34 provinces. "Guidance on Bathing Water Analysis (2006/7/EC)" for the Public Health Institution of Turkey - Public Health Laboratories Department and Public Health Laboratories of the 34 Provinces (12-17).

Data quality assessment and classification practice were done by pilot provinces Antalya, Çanakkale and İstanbul on the basis of 4 years data. The applications were disseminated to all other 34 provinces by transferring the information about the activities done by the pilot provinces through training and workshop.

Improvement studies on the web-based database which is currently used by the Public Health Institution of Turkey - Environmental Health Department, having web-address of http://cbs.cevresaglik.gov.tr and having 5 component as drinking water, bathing water, natural mineral water - spring water (bottled water), swimming pools and thermal waters were conducted in the direction of the requirements of 2006/7/EC EU Directive.

Web site having the web-address of www. yuzme.saglik.gov.tr was put into service for public information 
During the project 10 project steering committee meetings, eight inter-ministerial meetings, three pilot provincial meetings, three working group meetings, results oriented five trainings, one seminar, five workshops, five study visits and various local visits were achieved.

The project had a web site under the address of http://www. aquacoope.org/turkeybw/.

\section{DISCUSSION}

TThe first European bathing water legislation, "Council Directive concerning the quality of bathing water 76/160/ EEC has been transposed to the Turkish Legislation by the Ministry of Environment and Forestry with the By-Law on Bathing Water Quality, which was published in the Official Gazette No. 260489, dated February 2006 (5, 18).

The By-Law on Bathing Water Quality defines the competent authorities that are responsible for monitoring and inspection of bathing waters, preparing permits for discharges to these waters, and preventing pollution in those areas. Monitoring activities in bathing and recreational waters are carried out by the Ministry of Health. However, the Ministry of Environment and Urbanization has the right to perform monitoring activities in those waters if required. In lake and sea coasts that are conventionally used by a large number of bathers in the bathing season, the Public Health Directorates that are the provincial level of Public Health Institution of Turkey (central level) are carrying out microbiological monitoring studies at sampling points that are determined by the provincial commission established in accordance with the By-Law on Bathing Water Quality. In provinces the Public Health Directorates of Public Health Institution of Turkey also determine the bathing water sampling schedules for bathing season before the season. The Ministry of Health, Public Health Institution of Turkey sends the results of the monitoring activities to the Ministry of Environment and Urbanization/the Ministry of Forestry and Water Affairs. When the bathing water monitoring results reveal that there are deviations from the parameter values, the Ministry of Environment and Urbanization is doing the necessary inspections to prevent pollution in source. On the other hand, in accordance with the By-Law on Bathing Water Quality, inspection and monitoring rights of authorities defined in the By Law are reserved. In this scope, in order to protect environment and public health, these authorities may take preventive measures for potential pollution in bathing waters.

The By-Law on Bathing Water Quality involve not only the microbiological parameters and physicochemical parameters but also the guidance values, mandatory values, minimum sampling frequencies, methods of analysis and inspection of parameters as well for the quality requirements of bathing water. The microbiological parameters are total coliforms, faecal coliform, faecal streptococci, Salmonella spp., enteroviruses. The classification of bathing water during and at the end of the bathing season are done through the assessment of the analysis results of total coliform, faecal coliform and faecal streptococci with guidance and mandatory values. During bathing season the classification is expressed as good, average and bad quality while at the end of the season the classification is expressed as A (excellent quality), B (good quality), C (bad quality) and $D$ (forbidden).

The "Directive 2006/7/EC concerning the management of bathing water quality and repealing Directive 76/160/EEC" hasn't been transposed to the 
Turkish legislation yet. In the National Action Plan for EU Accession Phase II (June 2015-June 2019) the transposition period of this directive was given as second half of 2017. The transposition activities of this directive are being carried out in the coordination of the Ministry of Health with the contribution of the Ministry of Environment and Urbanization, the Ministry of Forestry and Water Affairs, the Ministry of Foreign Affairs and the other relevant institutions and organizations.

\section{CONCLUSION}

The technical and institutional capacity for the full implementation of the 2006/7/EC Directive both by the Ministry of Health - Public Health Institution of Turkey at the central level and the Public Health Directorates of the 34 provinces at the provincial level were improved successfully with the project.

This project was previously presented as poster in the National Water and Health Congress (19).

\section{ACKNOWLEDGEMENTS}

This project was co-financed by European Union and the Republic of Turkey. It is a twinning partnership between France, Italy (Member States) and Turkey (Beneficiary).

We would like to express our deepest appreciation to all those who provided us technical and administrative assistance, expertise, knowledge, cooperation and coordination to complete this project successfully. We thank our French partners from International Office of Water (IOW) (Office International de I'Eau) (OlEau), Ministry of Social Affairs and Health, Ministry of Ecology and Sustainable Development, Bureau of the French Water Agencies in Brussels, Laboratories of Paris and Nice, French Agency for Food Safety ANSES, BRGM (Bureau de Recherche Geologique et Minidre) and Italian partners from Fondazione Minoprio, Ministry of Health, the EmiliaRomagna Region ERR. Italian National Health Institute (ISS), Regional Environment Protection Agency Veneto (ARPAV/ISPRA), Regional Environment Protection Agency Emilia-Romagna (ARPAER/TSPRA), the Delegation of the European Union to Turkey, the Prime Ministry Undersecretariat of Treasury - Central Finance and Contracts Unit, the Ministry for EU Affairs, the Ministry of Health - Public Health Institution of Turkey - Environmental Health Department - Water Safety Unit.

We sincerely thank French and Italian colleagues Josiane MONGELLAZ (Former Project Leader), Pierre Chantrel (Project Leader), Andre Boschet (Residence Twinning Adviser), Brigitte Moissonnier, Laurent Pena, Bernard Hugues, Eric Mino, Olivier Coulon, Virginie Le Bris, Fulvio Ferrara, Benoit Gassiloud, Christophe Rosin, Florence Pintus, Chantal Trublet, Alexis Armengaud, Gilles Bidet, Thierry Panaget, Agnes Alexandre-Bird, Michel Marzin, Jean Duchemin, Melanie Archambault, Enzo Funari, Liana Gramaccioni, Emilia Aimo, Marinella Natali, Gianluca Girardi, Paolo Lauriola, Emanuela Testai, Maura Manganelli and Herve Tron. 
We deeply thank Turkish colleagues from Public Health Institution of Turkey - Environmental Health Department, Dr. Hüseyin ilter (Department head), Zinnet Oğuz (Unit coordinator, key expert), Alper Köșger (Result 4 expert), Şenol Yılmaz, İbrahim Çubuk, Yeliz Kurt, Mustafa Özdemir and all other Water Safety Unit staff. Special thanks to the pilot province colleagues Hüseyin Özyurt, Sait Şen, Metin Balcı, Erdem Atan, Adem Ceran, Idris Çelik, Emine K. Altunkaynak (İstanbul Public Health Directorate), Mustafa Karabulut (İstanbul Beykoz Public Health Center), Metin Kandemir, Hüseyin Yücel (Antalya Public Health Directorate), Funda Köseoğlu (Çanakkale Public Health Directorate), Gülben Koca (Bozcaada Public Health Center), Yasin Atakan (Biga Public Health Center), Azmi Nafi Uygun (Gökçeada Public Health Center).

\section{REFERENCES}

1. Anonymous. European Commission, "Institution Building in the Framework of European Union Policies Common Twinning Manual- Revision (2012), Update 2013-2014". http://ec.europa. eu/europeaid/institution-building-frameworkeuropean-union-policies-common-twinningmanual-revision-2012-update_en, 23.10.2014.

2. Anonymous. http://ec.europa.eu/enlargement/ tenders/twinning/index_en.htm, 12.01.2016

3. Anonymous. European Commission, DG Neighborhood Policy and Enlargement Negotiations-NEAR Institution Building TAIEX, Twinning, "Guidelines for Twinning Review Missions" Guidelines TRM, http://ec.europa. eu/enlargement/pdf/financial_assistance/ institution_building/2015/20150226-guidelinestrm-near.pdf, 2015..

4. Bartram J, Rees G. Monitoring Bathing Waters - A Practical Guide to the Design and Implementation of Assessments and Monitoring Programmes, Published on behalf of WHO, 1st ed. London: E \& FN Spon, 2000.

5. Anonymous. Council Directive $76 / 160 /$ EEC of 8 December 1975 concerning the quality of bathing water. OJ L031, 05.02.1976, p.1.
6. Anonymous. http://www.eea.europa.eu/themes/ water/status-and-monitoring/state-of-bathingwater/bathing-water-directives, 03.06.2016.

7. Anonymous. Directive 2006/7/EC of the European Parliament and of the Council of 15 February 2006 concerning the management of bathing water quality and repealing Directive 76/160/EEC. OJ L64, 4.3.2006, p.37-51.

8. Anonymous. EUROPEAN Environment and Health Information System "Bathing Water Quality" Fact Sheet 1.4 December 2009 Code RPG1_WatSan_S1 , 2016 WHO. http://www.euro.who.int/_data/ assets/pdf_file/0010/96967/1.4.-Bathing-waterquality-EDITED_layouted.pdf?ua=1, 2015.

9. Anonymous. http://ec.europa.eu/environment/ water/water-bathing /summary. html, 08.06.2016.

10. Anonymous. "Bathing Water Profiles: Best Practice and Guidance December 2009”, http://ec.europa. eu/environment/archives/water/report2011/ profiles_dec_2009.pdf, 08.06.2016..

11. Anonymous. "Alignment in bathing water monitoring" Project Fiche - IPA decentralised National programmes TR2010/0327.01 http:// ec.europa.eu/enlargement / pdf / turkey / ipa/2010/153_tr20100327.01bathingwatermonitor ing.pdf , 22.01.2016. 
12. Anonymous. "Guidance on Bathing Water Quality Monitoring (2006/7/EC)", 2015.

13. Anonymous. "Guidance on Bathing Water Quality Classification (2006/7/EC)”, 2015.

14. Anonymous. "Guidance on Bathing Water Data Management (2006/7/EC)”, 2015.

15. Anonymous. "Guidance on Cyanobacteria Proliferation in Bathing Waters (2006/7/EC)", 2015.

16. Anonymous. "Guidance on Bathing Water Profiles (2006/7/EC)", 2015
17. Anonymous. "Guidance on Bathing Water Analysis (2006/7/EC)”, 2014

18. Anonymous. The Ministry of Environment and Forestry, the By-Law on Bathing Water Quality, Official Gazette dated 09. 01. 2006.and No. 26048

19. Dikmen D, Oğuz $Z$, ilter $H$, Irmak H. Alignment in bathing water monitoring / Yüzme suyunun izlenmesinde uyum TR/10/IB/EN/02, TR 2010 / 0327.01 EU Twinning Project, Poster Presentation in the National Water and Health Congress with International participation. October, 26-30, 2015, Antalya-Turkey 